\title{
THE MORAL PSYCHOLOGY OF EUROPEANNESS: DIVERSIFIED, HORIZONTAL AFFECTIVITY ${ }^{1}$
}

\author{
Eric Brown ${ }^{1}$, Judit Szalai ${ }^{2}$ \\ ${ }^{1}$ Central European University, \\ Business School, \\ Budapest, 1023, Frankel Leó út 30-34 \\ E-mail: browne@ceubusiness.org \\ ${ }^{2}$ Department of Modern and Contemporary Philosophy, \\ Eötvös Loránd University, \\ Budapest, 1088, Múzeum krt. 4 / i \\ E-mail: jszalai@webmail.phil-inst.hu
}

\begin{abstract}
The question the authors of this paper raise is what kind of positive emotional attitudes the sustained, fruitful existence of the European Union (EU) takes on the part of its citizens. It is argued that the EU as a polity is an inappropriate object for patriotism. The emotions the authors envisage as constituting the necessary affective basis for the political community are based on developing horizontal relationships among citizens and their relationships to institutions that the EU makes possible.
\end{abstract}

Keywords: attitude, European Union, patriotism, political affect.

DOI: $10.3846 / 2029-0187.2008 .1 .172-185$

\section{Introduction}

How can highly pluralistic political communities perpetuate themselves over time? One potential answer to this pressing contemporary question is patriotism. A community that does not command an appropriate measure of patriotic attachment from its members may well appear to be too weak to be sustainable. Such an attachment is usually thought of as grounded in shared history, language, and culture (on more traditional conceptions of patriotism) or in a particular kind of political culture and systems of norms (in the case of constitutional patriotism).

The problem is especially topical in the case of the EU, a political community that is currently grappling with the problem of emotional-attitudinal integration, deemed to be a necessary complement to legal and institutional integration. The EU is intent on boosting sentiments of common identity; it is "a project, or more precisely, a desire of the administration of the European Union," to be achieved by means that are "subjectively affective"

1 Eric Brown presented parts of this paper at the Dubrovnik Inter-University Center seminar in social and political philosophy in March 2005. He extends thanks to David Rasmussen, William McBride, Martin Matustík, and Patrice Canivez helpful comments and discussion. Judit Szalai read an earlier version of her contribution at the workshop on European Patriotic Feelings at the Radboud University Nijmegen (2004, November 18-20). Thanks to her commentators, Katalin Farkas and Jean-Pierre Wils, as well as the other participants of the workshop. 
(Delgado-Moreira 1997). Such common identity is hoped to foster emotional commitment to the shared European political endeavor and the special bond between the community and its members that the unity and stability of the EU requires. This desired bond is often labeled "patriotism," not towards a nation-state, but the European polity.

Patriotism is primarily an emotional attitude. In spite of this, the issue of europatriotism has, to our knowledge, not been systematically taken up from the perspective of moral psychology (the branch of philosophy that addresses the relation between agents' attitudes, motivation, and normative phenomena) and the philosophical theory of emotions. A part of our aim in this paper is to make a start at filling in this gap.

The arguments in the first part of our paper are negative, set against the possibility of europatriotism. In the second part, we take a more positive tack and try to identify forms of affect that we believe work towards sufficient affective grounding for the political community. Our claim is that emotional attachment to the EU must be understood as based in new life possibilities and what we will call "horizontal" relations-connecting persons to institutions, projects, and other persons - made possible by legal and institutional structure of the EU and evolving social-cultural practices.

\section{Against the possibility of patriotism on a European scale}

According to its standard understanding, patriotism is, roughly, a kind of love for, pride in and loyalty to the polity to which one belongs as well as willingness to make sacrifices for that polity. It is also taken to involve concern for one's compatriots and putting their needs and ends above those of members of other polities (Primoratz 2002: 443). Although patriotism is sometimes defined in opposition to nationalism ${ }^{2}$, the distinction between the two is less than straightforward. Patriotism, as it is standardly understood today, also takes the nation-state as its object or target. That is, like nationalism, it is also an attitude tied to historically specific forms of social and political life, viz., the modern nation and the modern nation-state.

Two main conceptions derived from political thought related to the nation-state have been offered as models for conceptualizing European-scale political attachment: constitutional patriotism and civic nationalism. Constitutional patriotism is conceived of as a post-national source of identity and social solidarity: simply put, it is a kind of love for and shared loyalty towards one's own historically particular political community as embodying liberal-democratic principles. Jurgen* Habermas believes that, due to these characteristics, constitutional patriotism can be an affective bond between European citizens and between European citizens and the EU (Habermas 1996: 507). Constitutional europatriotism, it is claimed, is shorn of pre-political nationalist and ethnic content and is directed to and given content by the liberal-democratic political culture of a unified Europe.

Another major option besides constitutional europatriotism would be the European analogue of civic nationalism. Civic nationalists hold that the affective bonds between

2 In the recent literature, see, e.g., Li and Brewer 2004 and de Figueiredo and Elkins 2003. 
co-nationals, conceived as a relatively culturally homogeneous body of persons, are a precondition of sound democratic deliberation. Democratic deliberation requires compromise, sympathy, and sense of common purpose, which come only when one is deliberating with others who are similar to oneself. Thus, a European analogue to civic nationalism would require a sense of shared culture and history as well as a significant measure of like-mindedness among citizens of the EU countries.

An assumption we share with those who argue for some form of europatriotism is that emotional attachment is necessary for the long-term survival of a political community. But what kinds of emotions make sense in the context of the EU? As we will argue, the European Union as a political community is the wrong object of any kind of patriotism.

\section{The normativity of affect: inappropriate and meaningless emotions}

The wrong objects can make emotions meaningless or inappropriate. In the case of meaningless emotions, the semantic or logical properties of the emotion term exclude the application of the term to the case in question. The impossibility of patriotic love for the EU, as we conceive it, is not a logical-semantic issue, however. We more or less understand what it would mean for the EU to be a target of patriotic emotions, in a way that we do not understand the notion of anticipatory excitement with a target event that took place a hundred years ago. Confining the meaning of patriotic love to necessarily having a single state or country as its target would beg the question against europatriotism. Rather, our claim is that the EU is an inappropriate object of patriotism. This inappropriateness is in part due to contingent, historical circumstances. Like regret, romantic love, and disgust, patriotism has specific constraints on its possible objects, some of which the EU as an object does not meet. Later on we will try to spell out those constraints that exclude the EU from the circle of possible objects of patriotic emotions.

\section{Europatriotism and constraints on the object of patriotism}

What is the object of patriotism, at which patriotic feelings are directed? Somewhat platitudinously, according to the original meaning of the term, patriotism involves love of and loyalty to a patria, a "homeland", which usually corresponds to some self-standing political unit, typically a single state or country. Now, patriotic attachment, just like many other emotions, has certain cognitive preconditions, that is, beliefs without which the emotion cannot occur. A cognitive precondition of patriotism, we claim, is the belief in our territorial-political unit as an original source of value, that is, the belief that it has special worth and interest over and above enhancing the worth and serving the interests of its members. This worth and interest made vivid by the "founding myths" of the political community, ground citizens' readiness to make sacrifices for that community. The value attached to the political community is seen as an original, quasi-natural, given source of value and meaning, one that is given reasonable priority by the members of that community in their actions and allocation of resources. We will claim that the EU is deficient on this score. We will call this the originality problem. 
Another account on which the idea of europatriotism fails is a precondition of love, the most fundamental emotional component of patriotism, the one that grounds the rest of the affective elements (pride and loyalty to the political community). Love, as we will argue, presupposes a sufficiently thick conception of its object. At least presently, the EU does not seem to meet this subjective requirement. This issue will be labeled the robustness problem. A further claim that we will try to substantiate is that the robustness problem cannot be overcome by focusing on liberal-democratic principles embodied in the polity (constitutional europatriotism) or on common culture and history (some analogue of civic nationalism).

\section{Europatriotism and constraints on the object of patriotism: originality}

There are two aspects of the originality of the political community as a source of value. We could label these historical originality and evaluative originality. Along the historical dimension is the community's quasi-natural, given status in the perception of the patriot. While it is a near truism that nations are historically contingent constructions, if they are to call forth patriotism, they cannot present themselves primarily as such. The patriot qua patriot does not see the origins of her political community in terms of social-economic forces, ambitions, and political maneuvering. Rather, she conceives those origins in terms of a scheme of values and associated stories ("myths").

Along the evaluative dimension, we have the unmediated valuation of the community by the patriot, which largely derives from the first, historical element. By unmediated valuation we mean that the patriot's devotion to his/her nation is not dependent upon or mediated by other objects toward which she has evaluative attitudes or emotions. This is not to say that the patriot cannot see her nation as, for instance, supportive of her personal ends and goals; however, her benefit is not the measure by which the nation is to be assessed. The value of the nation and its meaning in the patriot's life are not seen through the lens of the patriot's personal interest or gain.

How does the EU fare on this score? In the case of the EU, the values, ends and goals that may stand in the way of unmediated regard for those of the European polity are nation-level ones. The developments of the past few years are disconcerting in this respect. In certain countries, considerations of internal politics have been very significant, or even decisive, with regard to the referenda on the EU constitution. Also, there were immense difficulties around accepting a budget for the period of 2007-2013, due to the protests of leading countries about being "overcharged" and the protection of the agricultural interests of certain countries. There was a chance of the common political endeavor being jeopardized in order to reduce the expenses of the member countries. On the basis of these events, it does not seem unfair to say that the worth of the EU is, to a large extent, seen through the lens of individual interests and priorities of the countries, and the EU does not represent enough of a unique value for a reasonable reconsideration or (at least temporary) downplaying of those.

Nor is it the case that, although decision-makers of the member countries are against sacrifice for the EU for its own sake, public opinion is for it. In general, citizens' attitudes 
to the EU seem to be mediated by their attitudes to their nation states. As Sylvia Kritzinger shows, the evaluation of the Europeans of the EU is dependent upon their evaluation of the current prospects of their nations: greater approval of the EU is correlated with greater disapproval of one's nation state and lesser approval of the EU is correlated with greater approval of one's nation state (Kritzinger 2003). It seems that citizens of European countries that do not do sufficiently well are hoping that the EU will make up for this, while citizens of countries with great approval hope that the EU will at least not hinder the maintaining of their achievements - in neither case is the EU's own interest the primary consideration. This hardly presents the EU as the kind of original and independent source of value and meaning that patriotism would require. Rather, the EU is of value to citizens relative to their expectations for their nations.

It could be objected that the fact that the commitment to one's own country has priority over commitment to the EU does not mean that patriotism is failing with regard to the EU - it takes second place, after the allegiance to one's individual country. Indeed, we do not deny the possibility of multiple sources of identity and value. The problem is not that the EU is only second to one's own country - that would be compatible with the EU also having unmediated value for the citizen. Rather, the problem is that nation-level values and priorities seem to get in the way of sufficient regard and sacrifice for the EU. Failing to accept a budget for the EU might have put the existence of the EU in danger, while, compared to this, accepting a less than ideally advantageous one would have done little harm to individual countries. Valuing something, in our case the EU, involves certain action tendencies, tendencies to make reasonable sacrifice - otherwise, we have to see the valuing as sham, as mere rhetoric. If national interests consistently take precedence over those of the EU, moreover, less-than-critical national interests take precedence over vital interests of the EU, this casts doubt upon the value the EU represents for countries and individuals.

The evaluative originality problem does not show that the EU must be the wrong object of patriotism. The present situation could be a matter of present historical contingency with a fair chance of changing with time. However, as we have indicated, the problem of evaluative originality to a large extent goes back to that of historical originality. The content of the EU's historical narrative hardly allows for the kind of historical originality that patriotism would require. Besides securing certain economic advantages, a primary motivation for the agreements among Western European countries that laid the foundations of today's EU was to create a durable counterbalance to and, at the same time, smoothly reintegrate West Germany into the community of Western European countries after WWII. A further goal was to counterbalance the two Cold War superpowers, the United States and the Soviet Union. For the six original states, European security was and still is "a powerful influence on governments and politicians" (Pinder 2003: 2-3). Most of these political aims, as well as economic expectations with which different countries and regions joined the EC and the EU, have been publicly aired and negotiated.

It is not just the content of the EU narrative that militates against historical originality, but the conditions under which this narrative has been formed to do so as well. Europeans have watched a rather messy evolution of the EU over the course of decades. Whereas 
the construction of nation-states by political and intellectual élites could go on somewhat behind the backs of the populace in the $18^{\text {th }}$ and $19^{\text {th }}$ centuries, the construction of Europe in the $20^{\text {th }}$ and $21^{\text {st }}$ centuries has gone on before their eyes. Indeed, the very nature of the construction of Europe after WWII required public democratic transparency. Citizens have participated in this public construction, have reflected and continue to reflect on it. It cannot be seen by them as given, as immediate or quasi-natural.

"Immediacy" and a "quasi-natural" character, on our account, should not be equated with the ethnic or the pre-political one. Rather, it is a description of the formal character in which a polity must present itself to citizens in order to be capable of being an object of patriotism. Nothing requires these formal characteristics to be present in the polity's presentation of itself as grounded in pre-political ethnic or national identity. In this respect, constitutional patriotism, which does not rely on such identities, could be an equally good candidate as a model for europatriotism.

While, in the case of the EU, unmediated valuation of the political community would certainly not be possible on the basis of common ethnicity, could constitutional patriotism provide unmediated valuation we are after? The answer is in the negative. The EU's "constitutional" embodiment of liberal democratic principles and neutral procedures of decision are not seen, and not likely to be seen, in any way independent of, or original relative to, similar national constitutional traditions. Everywhere within the EU, human rights, democracy, and the rule of law are embodied in the (however recent) constitutional histories of the member nations. For a nation state, to suitably uphold these principles is a condition for membership in the Union in the first place. These values are not attached primarily to the EU, but, more perceptibly to the citizen, to his/her own country.

\section{Europatriotism and constraints on the object of patriotism: robustness and singularity}

In the previous section, we tried to advance the claim that the EU is the wrong target for patriotism, for its history undermines the cognitive precondition for that attitude. The following argument is meant to support the statement that the concept of love, a necessary element of patriotism, also has conditions that are unlikely to be met in the case of the EU as a putative object.

Love is an intense feeling of wanting to "willingly join ourselves" (René Descartes) to a particular object, a disinterested concern for the well-being of that object (Frankfurt), a desire to form a "we" together with it (Robert Nozick). ${ }^{3}$ In order for such a tendency to arise, we need to have a fairly thick conception of, or acquaintance with, the object in question: we need to attribute a certain number of properties to it, properties that are sufficiently significant for us. ${ }^{4}$ Acquaintance with a single property, for instance,

3 Descartes 1985: 356; Frankfurt 2004; Nozick 1989. Although these definitions are primarily meant to describe love as a relationship between persons, they are sufficiently abstract to cover cases of love for non-human objects as well, especially as our understanding of love for non-human objects is modeled on the human case.

4 In one formulation, love is grounded in its object's "particular complex of instantiated qualities" (Brown 1987: 106). 
is certainly insufficient to induce love. One cannot love a person who invented the wheel as such or the building with the highest number of windows in the world as such. We need to know more about that person than the fact that he invented the wheel and more about the building than the fact that it has the highest number of windows. The object has to be well-determined from the subject's point of view. Moreover, the familiarity-real or imaginary - that love presupposes is with the object as a whole: we have to have a thick global conception of the object itself, rather than of some part or manifestation of it (that in our appreciation we sometimes globalize from details or effects is a different issue).

Is the robustness of the citizen's concept of Europe and the EU sufficient to support it as an object of patriotic love? Our answer is once again in the negative. As Thomas Risse has put the problem, the EU lacks "realness" for its populace (Risse 2003: 4). One of the reasons he cites is the fuzziness of the boundaries of Europe. At least for now, the EU is not well-determined in terms of who is in and who is out. Even if, with time, the more permanent boundaries of the EU are set, whether a particular country wishes to join, stay out of or remain within the EU will always be revisable and subject to current interest pressures. Since it is not clear what Europe as a political unit corresponds to in terms of what it includes and excludes, we are treading unstable ground when trying to attribute properties to it as a whole.

Does constitutional europatriotism fill our concept of the political community with robustness via the liberal-democratic principles realized in it? We believe it does not. For, as it has been convincingly argued, the EU seems less than real to its citizens on another score as well besides the fuzziness of its boundaries. It is the national authorities that implement EU regulations; thus, it is claimed, the EU disappears behind them (Risse 2003: 3). National authorities often shift blame for unpopular measures to the EU, and the actual responsibility for measures and regulations is not clear to the citizenry (Risse 2003: 3). The dedication of the EU to democratic principles is a matter of abstract knowledge for them, and the way in which principles are embodied in concrete political institutions is hardly perceptible. Of course, things may take a positive turn: in connection with particular problems that come up, clashes of national practices and EU regulations, EU debates over regulations and national debates over their implementation, the sources of regulations may be more clearly perceived in the future. Will this make for more (constitutional) patriotic feeling towards Europe? If the outstanding feature of the EU, the feature that is supposed to be the basis or focus of patriotic love, is the embodiment of liberal-democratic principles, the idea of europatriotism faces opposition on account of a further characteristic of love (as the leading emotional constituent of patriotism): the perceived singularity of its object.

The object of love has to be, or has to seem to its subject to be, in some respect irreplaceable or singular, representing a sui generis value. As David Velleman explains in the context of love between persons, the substitution of one object (the person loved) for another cannot preserve the same value, for the two are of incomparable worth (Velleman 1999). In what way could we see the EU as irreplaceable, as representing a value of its own kind? (The problem is not quite the same as the one we covered before, that of evaluative immediacy. Something can have unmediated but non-unique value; also, unique 
value can be mediated - for instance, I may appreciate a special kind of cheese produced in one region only because I am fond of the risotto that can be prepared with it.)

It does not appear to be the case that the EU is irreplaceable as a repository of value. As to liberal-democratic values, which, as we already discussed, would ground patriotic love for the constitutional europatriot, these values are dominant values in the political cultures and institutions of the member nations as well; thus, the EU is far from singular in embodying them.

How about the often-mentioned "shared European history", "culture" or "heritage", which would seem to meet the singularity criterion? This proposal, in our view, fails on account of "European culture" lacking well-definedness and robustness. As Perry Anderson observes, not only are there no obvious geographical boundaries of Europe, but its cultural boundaries "are no more clearly marked than the geographical: Muslim Albania and Bosnia lie a thousand miles west of Christian Georgia and Armenia, where the ancients set the dividing-line between Europe and Asia" (Anderson 1997: 139). But even if we grant that there is some kind of well-defined cultural core to Europe, this core seems to be insufficient as a focus of patriotic love for Europe. As the history of Europe itself illustrates, shared history and culture, if we can talk about these in the European case, do not make for peaceful coexistence, let alone for a sense of belonging to a single community - we might think of the permanent wars and conflicts for power among those countries that later came to found the EU.

Nor is there reason to think that political unification itself, which, as we have discussed, took place with a view to explicit political and economic goals, would turn the attention of the citizenry towards a shared heritage or inspire a more acute sense of it. In reality, an opposite tendency seems to be unfolding: with the EU, Europe's political aspects seem to be increasingly dominant. In 2002, none of the groups of respondents from Germany, Austria, Great Britain, Italy, Spain, Greece, Poland, Hungary, and the Czech Republic put "language/culture" to the first place as grounds for European attachment (Ruiz Jiménez et al. 2004, Table VII). What was most frequently mentioned in the first place is the "freedom of movement and residence", with "economy" also among the most important elements.

While constitutional patriotism envisaged on the European scale is vulnerable to the previously mentioned problems, lack of a perceived homogeneity of culture and adherence to such a culture is a problem for those conceptions that would have some analogue of civic nationalism applied to Europe. Thus, with the alternative ideas of europatriotism equally facing serious difficulties, some other form of political affect needs to be explored as binding citizens to the EU.

\section{Non-patriotic emotional attachment to the EU}

The broad category of "emotions" covers a heterogeneous group of mental states: moods (typically thought to be objectless), "programmed," immediate affects, like disgust or fear, and socially acquired attitudes involving a more significant cognitive element, like gratitude or shame. If we consider only the "loud" emotions traditionally focused on, such as 
love, hate, anger or grief, having emotions seems to be the exception rather than the rule in our mental lives. In contrast to this understanding, we find a different conception of emotional life attractive, which, albeit infrequently thematized, is probably more widespread today than the traditional one. According to this more plausible picture, we have emotions all the time, which can, however, rarely be identified as straightforward cases of, e.g., gratitude, hate, or pride. We are emoting even in our most "rational", "undisturbed" moments: we are interested or bored when reading a book in a leisurely hour, feel doubtful or certain when solving a problem, anxious that we have not taken a number of factors into consideration when deciding who to vote for.

Emotions with identifiable, localized brain processes, such as fear or lust, are the most universal, "ancient" ones, while the culture-dependent emotions are not hardwired and are contingently intermingled with different cognitive processes in the brain. The emotions in this latter category are typically known in certain cultures only and are tied to specific kinds of objects or objects perceived in specific ways. Above, we have seen some constraints on possible objects of patriotism, an emotion that belongs to the latter category. In this section, our claim will be that patriotism is not the only affective option for allegiance to Europe. There are emotions that, without necessarily being immediately directed at the political community as such, can jointly and indirectly make for a complex positive attitude towards it. These emotions resemble patriotism in that they are not hard-wired, "ancient", but adapted to the current socio-political circumstances in their objects, intensities and action tendencies.

\section{The European Union and diversified political affectivity}

As surveys have revealed, Europeans are attached to Europe. The recent levels of professed attachment in the member countries have been around 67 percent (Anon 2005: 103). According to 2004 Eurobarometer data, around 40 percent of the citizens in most EU member countries would have been "very sorry" if told that the European Union had been scrapped, and only 13 percent would have been "very relieved" (Anon 2005: 86).

The question of whether one is attached to the EU (or to Europe, as the two are often not distinguished) is too coarse-grained, however. There can be very different grounds for and foci of attachment to the same object. It has been claimed in the philosophical theory of emotions, in our view plausibly, that emotions are subject to the so-called "viewpoint constraint": their objects are objects from the particular viewpoints of their subjects (Gunther 2004: 46-7).

What do we value when we value the EU, that is, what are the grounds of attachment to it? The political institutions of the EU? Fellow-ship with other Europeans? The advantages we may expect out of the EU? Citizens of different countries give different rankings of the features of the united Europe they value or with which they identify: economy, language, culture, rights, the military, etc. (Ruiz Jiménez et al. 2004, Table V). As the Eurobarometer data show, whereas attachment to one's own nation has to do with language, culture, history, symbols etc., attachment to Europe primarily has to do - for the majority of the respondents - with what are called "instrumental" goods such as 
free movement and residence and single currency (Cf. Ruiz Jiménez et al. 2004: 10; Miller 1995: 160).

It is a common understanding that the European polity itself is an ongoing project, that it has no definite nature as yet, or even perhaps none to be aimed at, given the unprecedented character of the process of European integration. Some, more radically, claim that the totality of institutionalized European co-operation cannot be explained within a single framework (Anderson 1995: 465); that the EU is a "prosaic" political entity, a cooperative and pluralistic network with a focus on quotidian economic, cultural and social issues rather than being unitary in character and vision (van Ham 2001: 14); that there is no homogeneous "European identity" to be unearthed. What we will have to say about the affective side of Europeanness reflects the fragmentedness of the European experience that corresponds to the institutional divergence and cultural heterogeneity of the European polity as well as the ongoing character of European project.

Emotions are of innumerable kinds. Arguably, most of these are too transient, idiosyncratic and low-key to bear a name. Mental states and actions that are not themselves identified as emotions have "affective sides". Political participation and involvement are also "emotionally tainted". People vote because they prefer to feel significant, to feel that they have some control over what happens to them, or out of a sense of duty, which is also quasi-affective; they watch the news, often several times a day, to keep "well-informed", which often has more to do with how people feel about themselves than with the knowledge they can reasonably expect to obtain; persons' attitudes toward various political positions are emotionally laden.

EU choices have import for Europeans, who attach positive or negative values to the outcomes. EU-related referenda and elections are salient enough for Europeans to participate. Eurobarometer data show that high percentages of the populace took an interest in the draft constitution. On the broad view of emotions we are advocating, these are not "cold", "rational" processes, but expressions of some (emotional) commitment to the common cause, even if they fall short of big classical emotions like the "love of one's country." Europeans seem to have the necessary minimal affective basis to be "good citizens" of Europe.

Besides the affective component of political participation, as the data cited above show, European citizens do exhibit special attachment to Europe, if not for the reasons that the advocates of europatriotism would find desirable. What the data show is that Europeans see important and new life options in Europeanness. Significantly, 70\% put freedom of movement and residence in the first place in articulating their grounds of attachment to Europe. In many countries, economy / single currency occupies second place. We should not see this as an expression of "mere interest" as opposed to some more "noble" emotional attitudes; rather, it is an emotional attitude with a different focus. The things Europeans value highly in the EU have to do with their modes of life. It is not the case that these things cannot secure emotional attachment. On the contrary, the freedom of residence and movement, for instance, concerns citizens very directly, thoroughly influencing their life options - thus, are not far-fetched to "feel about". Whether we endorse such attachments or not, however ignoble or mistaken we may 
find them, there is no reason to single out the above as impossible grounds of attachment (at the same time, as it should be sufficiently clear from the arguments below, we do not advocate focusing on self-interest instead of community-feeling).

"European attitudes" have been studied by anthropologists looking at European organizations, research institutes, and companies with personnel from different countries. In these institutions, the actual practice of interchange and working together does not seem to foster feelings of sharing a common historical culture. Rather, as anthropologists have found, national stereotypes are very much in the forefront of attention at such workplaces (and often actually facilitate cooperation, especially by helping to get over initial difficulties). European institutions have to develop their "cultural compromises", part of which is permanent clarification and reworking of the usage of terms, which results in language that is often denounced as opaque and cumbersome (Zabusky 2000: 181).

If not a feeling of sharing the same traditions and culture, other shared affective attitudes have been described as typical in these institutions. Employees find it exciting, indeed exhilarating and liberating to shed limitations of national practices, express "reservations about returning to national environments, worried that they might find it 'narrow' or 'boring"' (Zabusky 2000: 181). An increasing number of people are committed to a new mode of life that involves high mobility, close bonds between people located at a distance, facilitated by new technologies of communication and inexpensive travel. These tendencies are self-reinforcing. For instance, with the rapidly growing number of inter-national marriages, people end up working and living away from their native countries; at the same time they keep up contacts with their home environment, frequently travel back and forth, make further contacts at both places that mediate yet further ones.

\section{The EU as constitutive means: vertical and horizontal attachments}

Attachment on the grounds of individual life options is not all there is to affectivity with regard to the united Europe. The EU, in our understanding, is not a mere means to preconceived ends that has only instrumental value to the individual. For now, citizens seem to support the widening of possibilities, material and otherwise. These possibilities will influence their future goals and ends. These ends themselves are in the process of unfolding, and many will involve "European" projects. Ends can be found by virtue of the opening of possibilities that did not exist before, just as computer technology made possible ends that no one could have conceived of prior to its advent. Thus, the EU could be called constitutive means: a means that is not distinct from the ends aimed at in the projects, goals, and enterprises it makes possible 5 .

An assumption of the promoters of the europatriotic idea is that a single focus of loyalty needs to be found, one that will secure citizens' allegiance to the EU. However, there is no reason to think that without such a special and shared focus people would not have a sufficiently positive affective attitude towards the EU or would fail to make sufficient sacrifice for it. What we would like to suggest is a model of political attitudes

5 On “constitutive means" see McDowell 1998: 7. 
based on horizontal affects. Such affects relate EU citizens to common projects, goals, and enterprises (in a broad sense) and to each other as participating in these. Such enterprises are made possible by the legal and institutional framework the EU has established, and extend to social life, political programs, and academic and intellectual endeavors. The transgression of national boundaries, in a cultural, professional and social sense, at times also involving some measure of physical transgression, is integral to our understanding of the motivational texture of Europe.

In our model, affects are generated not by centralized and common allegiance to a polity, but rather by de-centered and overlapping attachments. Citizens can adopt a positive emotional stance towards the EU that manifests itself in experiencing emotions with positive valence associated with the endorsement of the life options and cultural horizon the EU offers and in which the EU is a constitutive means, along with the affective side of political participation that makes for "good" citizenship without a special "patriotic sentiment" or robust "feeling of identity". The possibility of sacrifice for the EU may be secured due to citizens' adherence to the forms of life, ways of thinking of social and professional interaction that would be unknown without the EU. With the development of the political community, the multiplication of European institutions and social practices, such emotional ties are very likely to get strengthened and ramified. In the process, the vocabulary, that describes emotional attitudes to Europe, itself will get enriched and more precise.

We can contrast the suggested model with the structure of patriotism. A patriot feels solidarity for his or her compatriots by virtue of their common relation to the nation. Patriotic affect links each to the nation and through it to each other. If we think of the citizens at one level and the nation on a higher level, we can express the idea by saying that citizens are related to each other through their vertical relationship to the nation. On this model, the nation functions as the focal point for emotions and attitudes that in part make up the "imagined community".

Bringing the EU constitution to life could perhaps have provided a chance for the reinforcement of citizens' vertical relationship to the EU (although we find the tendencies mentioned under the heading of the originality problem far too powerful to be capable of being counteracted by a constitution). However that might be, horizontal relationships between citizens of different countries, between civic associations and businesses, facilitated by the more open environment the EU is creating, gain in importance. In our view, these horizontal relationships and flexible life options, secured of course by the success of European welfare values, are going to be a source of allegiance to European institutions. Thus, "vertical" relationships to the EU are realized via horizontal relationship. It is not allegiance to or love of some central and sovereign source of value located above citizens that primarily engage Europeans as Europeans. The order of the horizontal and vertical axes is the opposite of that in the case of patriotism, which is directed at the nation state. 


\section{Conclusions}

As we have tried to show, patriotism is an emotion that is not applicable in the case of the new type of political formation the EU is (whether or not it remains the one instance of its kind). We believe that the kind of affectivity towards the description of which we meant to make some rudimentary steps may prove enough to sustain the motivational basis of the EU. The fact that such are likely to be the most vehement emotions the EU can get does not mean that the emotional basis for a "real" political community is lacking. Rather, our view of political affectivity itself has to change with the altered circumstances that give rise to new kinds of emotions.

\section{References}

Anderson, J. 1995. "The State of the (European) Union: From the Single Market to Maastricht, From Singular Events To General Theories", in World Politics 47(3): 441-465.

Anderson, P. 1997. “The Europe to Come”, in The Question of Europe, ed. by P. Gowan, P. Anderson. London: Verso.

Anon. 2005. Standard Eurobarometer 62. Available from Internet: <http://europa.eu.int/comm// public_opinion/standard_en.htm>.

Bellier, I.; Wilson, T. 2000. "Building, Imagining and Experiencing Europe: Institutions and Identities in the European Union", in The Anthropology of the European Union: Building, Imagining and Experiencing the New Europe, ed. by I. Bellier, T. Wilson. Oxford: Berg, 1-27.

Brown, R. 1987. Analyzing Love. Cambridge: Cambridge University Press.

Descartes, R. 1985. "The Passions of the Soul”, in R. Descartes, The Philosophical Writings, vol. 1, Cambridge: Cambridge University Press, 325-404.

Delgado-Moreira, J. 1997. "Cultural Citizenship and the Creation of European Identity,"

in Electronic Journal of Sociology 2(3). Available from Internet: <www.sociology.org/content/ vol002.003/delgado.html>.

Figueiredo, R.; Elkins, Z. 2003. "Are Patriots Bigots? An Inquiry into the Vices of In-Group Pride", American Journal of Political Science 47(1): 171-188.

Frankfurt, H. 2004. The Reasons of Love. Princeton: Princeton University Press.

Gunther, Y. 2004. "The Phenomenology and Intentionality of Emotions", Philosophical Studies 117(1-2): 43-55.

Habermas, J. 1996. Between Facts and Norms. Cambridge, Massachussets: The MIT Press.

Kritzinger, S. 2003. "The Influence of the Nation-State on Individual Support for the European Union", European Union Politics 4(2): 219-241.

Li, Q.; Brewer, M. 2004. "What Does It Mean to Be an American? Patriotism, Nationalism, and American Identity After 9/11", Political Psychology 25(5): 727-739.

McDowell, J. 1998. "The Role of Eudaimonia in Aristotle's Ethics", in J. McDowell. Mind, Value, and Reality. Cambridge, Massachusetts: Harvard University Press, 3-22.

Miller, D. 1995. On Nationality. Oxford: Oxford University Press.

Nozick, R. 1989. "Love's Bond", in The Examined Life: Philosophical Meditations.

London: Simon \& Schuster, 68-86.

Pinder, J. 2003. The European Union: A Very Short Introduction. Oxford: Oxford University Press.

Primoratz, I. 2002. "Patriotism: A Deflationary View", The Philosophical Forum 33(4): 443- 458. 
Risse, T. 2003. "An Emerging European Identity? What We Know, And How To Make Sense Of It". Available from Internet: <www.helsinki.fi/collegium/events/europeanidentity.pdf $>$.

Ruiz Jiménez, A. et al. 2004. "European and National Identities in EU's Old and New Member States: Ethnic, Civic and, Instrumental and Symbolic Components", European Integration Online Papers 8(7). Available from Internet: $<\mathrm{http}: / /$ ideas.repec.org/a/erp/eiopxx/p0116.html $>$.

van Ham, P. 2001. European Integration and the Postmodern Condition: Governance, Democracy, Identity. London: Routledge.

Velleman, D. 1999. "Love as a Moral Emotion”, Ethics 109(2): 338-374.

Zabusky, S. 2000. "Boundaries at Work: Discourses and Practices of Belonging in the European Space Agency", in The Anthropology of the European Union: Building, Imagining and Experiencing the New Europe, ed. by I. Bellier, T. Wilson. Oxford: Berg, 179-200.

\title{
MORALINĖ EUROPIETIŠKUMO PSICHOLOGIJA: IVAIRUS HORIZONTALUSIS AFEKTYVUMAS
}

\author{
Eric Brown, Judit Szalai
}

\begin{abstract}
Santrauka
Straipsnyje keliamas klausimas - kokiomis pozityviomis emocinėmis nuostatomis remiamasi, siekiant Europos Sajungos kaip ilgalaikès produktyvios institucijos poveikio emocinèms jos piliečių nuostatoms. Teigiama, kad Europos Sajunga negali būti patriotizmo objektas, nes ši institucija nesuderinama su patriotinèmis emocijomis. Emocijos, neatsiejamos nuo visaverčio politinès bendruomenės egzistavimo, pasak straipsnio autorių, paremti Europos Sajungos piliečių horizontaliųjų santykių plètra bei jos piliečių ir institucijų bendradarbiavimo plètote.
\end{abstract}

Reikšminiai žodžiai: nuostata, Europos Sajunga, patriotizmas, politinis afektas.

Received 30 May 2008, accepted 25 June 2008 